\title{
Surrogate Motherhood in Colombia as a Gender Situation
}

\author{
José Antonio García Pereáñez, Lina María Ríos Martínez, Jeisson Londoño Quiroz \\ American University Corporation, Medellin, Colombia \\ Email: jgarciap@coruniamericana.edu.co, linamariarios18@hotmail.com, jei.londo@gmail.com
}

How to cite this paper: Pereáñez, J.A.G., Martínez, L.M.R. and Quiroz, J.L. (2018) Surrogate Motherhood in Colombia as a Gender Situation. Open Access Library Journal, 5: e4943.

https://doi.org/10.4236/oalib.1104943

Received: September 25, 2018

Accepted: November 2, 2018

Published: November 5, 2018

Copyright $\odot 2018$ by authors and Open Access Library Inc.

This work is licensed under the Creative Commons Attribution International License (CC BY 4.0).

http://creativecommons.org/licenses/by/4.0/

\section{cc) (7) Open Access}

\begin{abstract}
Surrogate motherhood is an assisted human reproduction method. This method is developed when a woman, in this case, genetic substitute, commits to carry a baby with the obligation to deliver him/her to the contracting parties when he/she is born. This paper reports the analysis of "Surrogate Motherhood in Colombia as a Gender Situation", which was achieved by applying guidelines of qualitative research, investigating the Colombian Law, Jurisprudence, and Doctrine on regulation in issues of surrogate motherhood. It was found that this practice is violating the dignity of women, and gives a category of "thing" to the human being. In these two members of Centro Democrático political party, following a legal, social, and ethical study on surrogate motherhood, articulated the Bill 026, 2016, seeking to give a greater protection to women and children conceived under this method, after years of failed bills, as was the case of 037,2009 . This analysis concluded that this practice has been carried out in Colombia in a disproportionate manner, which entails the violation of human rights for both the unborn child and the newborn baby resulting from this practice, as well as for the other participants.
\end{abstract}

\section{Subject Areas}

Law

\section{Keywords}

Surrogate Motherhood, Affiliation, Human Rights, Women Dignity

\section{Introduction}

Social relations generate juridical phenomena, which in the development of their just reason seek to be framed in what is legitimate and legal. Surrogate mother- 
hood as a method of assisted reproduction is one of these figures, which has had both positive and negative connotations, since it is based on subjective situations resulting from surrogate motherhood. These situations generate free confrontations of an axiological nature regarding surrogate motherhood and the need for regulation. It is necessary in this text to develop the basis, purpose, and application of surrogate motherhood in Colombia, and the imperative need to align this practice of assisted human reproduction with a series of human rights violations against the surrogate mother, considering surrogate motherhood as a form of "persons trafficking" and an exploitation of women for reproductive purposes. In addition to the violation of the rights of the unborn child, resulting from this practice of assisted reproduction.

The problems arising from surrogate motherhood or commonly called belly rental generate moral, social, economic, and political questions among the participants in where surrogate motherhood is developed, such as the genetic surrogate mother or gestational surrogate mother and the contracting parents. The above-mentioned situation puts at risk the unborn and the newborn baby as a result of surrogate motherhood, since the right to filiation is the pinnacle of family rights. Custody, maintenance and care are derived from this right; and with this practice without any regulation, the delimitation or solution of which has the affiliate links between the creature and the interveners is not considered. This degenerates not only the mother-filial relationship, but also the legal situation among those involved in surrogate motherhood.

In the following text, the legal concept of surrogate motherhood in Colombia will be developed, as well as how this is a practice that violates fundamental and constitutional rights. In addition, Bill 026, 2016 will be extensively described. Next, the concept of filiation in surrogate motherhood will be argued and criticized in order to finally propose the conclusive state.

\subsection{Surrogate Motherhood: Judicial Situation in Colombia}

Surrogate motherhood in Colombia, as a legal procedure, is not limited because it is not allowed, but not prohibited. The surrogate motherhood of wombs is presented in an illegal and irregular manner, through a de facto contract, which never becomes legal. In Colombian law, for a contract to be valid, there must exist a capacity to be bound which is tacitly stipulated in the Civil Code, Article 1502. Surrogate motherhood within a contractual framework would only comply with three requirements referred to in article 1502 of the Colombian Civil Code [1]: the capacity to be bound by the person, free consent, and the lawful cause; while the object will never be lawful, on the understanding that in Colombia it is not possible to negotiate with the life of a human being.

In surrogate motherhood there is a precedent in Colombia, as far as legislative initiative is concerned, and it is the bill 037, 2009 [2], presented on July $21^{\text {st }}, 2009$ "through which procedures to allow throughout the national territory the practice of surrogate pregnancy using assisted human reproduction techniques and 
other provisions are dictated". The initiative began with the aim of establishing the practice of substitutive gestation, through assisted human reproduction techniques, establishing in the same way the effective mechanisms for carrying out this practice.

Bill 037/2009 showed the lack of legal regulations regarding surrogate pregnancy or commonly called uterus rental, womb rental or surrogate motherhood. The bill's rapporteur, Jorge Ignacio Morales Gil, reports that he did not use the term "surrogate motherhood", because the term "maternity" encompasses countless legal institutions that go beyond giving birth to a human being. Nor was the wording of this bill adapted to the term surrogate motherhood or uterus rental, since in due form the existence of a lease contract and the legality of the object itself, which falls within the Colombian legal system, would be disputed. It is not healthy to take as an object a creature that is gestated in a maternal womb, in addition to the fact that this name, both semantic and social, causes a direct violation of the creature's rights.

Substitutive gestation, because of its social sensitivity, required a thorough analysis of its scope at the social, economic, legal, ethical, and medical levels, which led to the conclusion that it is only a viable mechanism in assisted human reproduction.

Bill 037/2009 was shelved, because although it passed the debates in the House of Representatives, according to Law 5/1992, specifically article 190, it was shelved by transit of legislature, and the Congress did not reintroduce bills on surrogate motherhood until 2016. In that year, three draft laws on the subject were presented: Bill 202 of 2016, Bill 056 of 2016, and Bill 026 of 2016.

\subsection{Bill 026 of 2016: Surrogate Motherhood as a Violating Practice of Fundamental and Constitutional Rights in Colombia}

After several years of inactivity regarding the presentation of the bill on assisted human reproduction and surrogate motherhood, in 2016, a new step was taken by legislators to present projects on scientific and technological development, with the purpose of improving the quality of life of Colombians. One of these projects is Bill 026 of 2016.

For this reason, the continued legislative silence on surrogate motherhood in Colombia led the honorable congressmen, Santiago Valencia González, representative of the House of Representatives and María del Rosario Guerra, senator, active members of the political party Centro Democrático, to push forward with Bill 026 of 2016 [3], an initiative of their own in the issue of surrogate motherhood. This was the purpose of the above-mentioned project: "By which the practice of renting Wombs in Colombia is prohibited as a category of trafficking in persons and exploitation of women for reproductive purposes". The Bill seeks to prohibit the practice of surrogate motherhood based on the fact that it is merely a category of trafficking with persons and exploitation of women for reproductive purposes. 
In Colombia, the situation of poverty makes a large part of its population vulnerable, since if this trafficking with persons and exploitation of women were to take place, a crime would be committed, as defined in the Colombian legal system, Law 599 of 2000, Criminal Code, article 188 A [4]. The prohibitive character of Bill 026 of 2016, finds its end in the protection of the rights to dignity, equality, autonomy, intimacy, procreation, and health of women, as well as the right to life, dignity, identity, freedom, integrity and security of the unborn. The jurisprudence by Sentence T-223 of 1998, recognizes it as a subject of constitutional and fundamental rights, rights that in the practice of surrogate motherhood makes visible its violation, within which the right to identity is more relevant.

The Article of Law 1098/2006 [5], sets the Right to Identity:

Children and adolescents have the right to have an identity and to preserve the elements that constitute it, such as name, nationality and filiation, in accordance with the law. For this purpose, they must be registered immediately after their birth, in the registry of the marital status. They have the right to preserve their native language, culture and idiosyncrasy.

In Agreement 047 of 2011, the Constitutional Court mentions that the Political Constitution of Colombia protects and supervises the product of conception, which is configured with birth, a situation that, if it happens, constitutes the juridical existence of the person, before the law. "The life of the unborn embodies a fundamental value, for the hope of its existence as a person that it represents, and for its manifestly helpless state that requires the special protection of the State".

In Colombia, the only jurisprudential reference regarding surrogate motherhood is found in Sentence T-968 of 2009, jurisprudence that does not fill the constitutional void on the problem, because it is not specified in the text, whether or not surrogate motherhood is permitted. The judgment presents the weighting of rights between surrogate mothers and the unborn child, attributing to both rights and freedoms, inalienable and non-transferable. Judgment T-968 of 2009, contrary to helping to solve disputes in issues of surrogate motherhood, confuses with its imprecision, since the origin of the litigation studied in this Judgment is indeed surrogate motherhood, but this figure is obscured during the process and finally what is discussed are the rights in family law, of the child resulting from a consensual sexual relationship and not by maternity.

It is here that the need for legislation other than that proposed in the aforementioned bill 026 of 2016 is estimated, suggesting greater protection, mainly for the rights of the creature, which is expected to be borne by means of this assisted human reproduction technique.

\subsection{Reasons for Bill 026 of 2016}

Bill 026 of 2016 passed the debate in the Senate; it does not preserve the interests and reasons for its establishment, since as discussed below, has been modified to 
be more "permissive" and leave the "absolute restriction" of surrogate motherhood in Colombian territory.

After the first speech in the House of Representatives, on bill 026 of 2016, a report was submitted for debate, for second discussion, as follows: "through which surrogate motherhood for profit in Colombia is prohibited and its practice regulated", justifying that "surrogate motherhood constitutes a real risk to the interests of the community by using the most vulnerable women and harming the interests of the child, who are subject to special protection" [3].

On November $2^{\text {nd }}, 2016$, Bill 026, established the same year, turned and took a new stance on the subject of surrogate motherhood. The First Chamber Commission approved the text, agreeing to a regulation that seeks to punish the practice of surrogate motherhood for profit, but waiving the absolute prohibition. In Bill 026 of 2016, the approved text contains in its articles the determination of the object, that is to say, the prohibition of the practice of surrogate motherhood for lucrative purposes, and the regulation for Colombian couples with infertility or gestation problems.

Any legal act in which the obligation to subrogate or rent the womb for profit is agreed shall be deemed null and void. Renting of wombs for altruistic purposes will only be allowed, and "altruistic" labor will be understood as solidarity human behavior that denotes concern or disinterested attention for the other, such as personal sacrifice for the benefit of others, without claiming profit, anything contrary to selfishness, among subjects that enjoy full capacity, among Colombian nationals, in cases of infertility or gestation problems.

Surrogate motherhood shall also be permitted where the consent of a woman who is related up to a fourth degree of consanguinity with one of the applicants and who is willing to be the surrogate mother is obtained. Article $188 \mathrm{E}$ of the Criminal Code will be added to its regulation in Law 599 of 2000, Article 188 E, where subrogated maternity for economic purposes will be typified and penalized.

Consequently, after the second presentation, the final text with amendments to Bill 026 of 2016, was approved in plenary session on $25^{\text {th }}$ and $26^{\text {th }}$ day of April 2017, "through which surrogate motherhood for profit is prohibited in Colombia and its practice is regulated" [3]. After the second debate was approved, the draft object of this article continues its legal and regulatory course, in compliance with the provisions of Article 182 of Law 5 of 1992.

\subsection{Juridical Filiation in Surrogate Motherhood}

Legal filiation in surrogate motherhood is a hot topic that has not been included in the Bills on this subject. This is a situation of great social and legal importance. Filiation is a universal right that must be respected to every human creature as a newborn. From it rights such as custody, alimony and care result. This right is understood as the juridical relationship or bond between two persons, where one descends from the other. 
The main obstacle to the regulation of surrogate motherhood in Colombia with regard to legal filiation is within the framework of maternal-filial relations. The discussion rests on which of the two women involved in the surrogate motherhood procedure is the mother of the child being procreated, which leads to determining the mother-filial relationship from which a series of rights and obligations are triggered.

It is understood that the title of "mother" in Colombia is acquired in two different moments from each other. The first one in childbirth, that is to say, the birth of the child is considered mother to be that woman who illuminates this newborn baby. Secondly, a woman who acquires a filial relationship with another person by adoption can be considered a mother [5]. In both cases the child acquires the same rights, but they acquire different kinship, since in the case of the adopted child, a civil kinship is reached and in the case of a child resulting from sexual intercourse, or a technique of reproductive assistance-where the descendants are proven by means of genetics-a blood kinship is acquired. With the title of "mother" and the moments involved, it is clear that in Colombia, up to the present day in a surrogate maternity procedure, the quality of motherhood, and therefore the maternal-filial relationship falls on the pregnant mother.

Notice that although the Colombian Civil Code has not raised issues of scientific development, it has a legal status, which at the time of having a surrogate motherhood, could be used-in the event of litigation. This figure is agreed in Article 335 [1]. However, the contracting mother also contributed her eggs to be inseminated, that is, that the child resulting from this maternal substitution possesses genes of this contracting mother and that the pregnant woman only lent or rent her womb to serve as a "cradle" or "incubator".

The adoption procedure is provided in the Childhood and Adolescence Law and is a suitable mechanism to supplement surrogate motherhood. Thus, in order to be able to acquire such an adoption, the pregnant mother will have to renounce all her rights over the child and leave these rights in the possession of the contracting parent.

After this, the contracting mother may adopt the child of her partner (may be spouses or permanent partners). In Colombia, this procedure can be carried out for the adoption of the couple's child, according to ruling C-683 of 2015 [6]. Persons who live together in a common-law marriage, even if they are homosexual, can invoke adoption. From all of the above, it can be inferred that adoption could be a good option for resolving the subsidiary dilemmas of surrogate motherhood.

\section{Discussion}

In the present moment and due to the axiological and legal conditions we Colombians live in, surrogate motherhood is presented as a gender situation. In this practice the violation of women's sexual and reproductive rights, the violation of their dignity, the exploitation of the right to procreate are visible. Also, 
the filial indetermination of the child resulting from this experience of assisted reproduction, which configures the "reification" of the woman who rents "her belly, the" objectification of the unborn and after the neonate, first as an object of consumption and then commercialization.

The presence of the contract in surrogate motherhood shapes this practice in the midst of supply and demand. They are offered for pressing needs to women who rent their womb to obtain an economic benefit. This "service" is demanded by couples who cannot have a child through sexual intercourse, shielded in their solvency for payment. One and the other make up an immoral situation of exploitation, in the midst of the legal laxity prevailing in Colombia on this practice of assisted reproduction.

The "hired" woman has the worst share of surrogate motherhood rent. Contractors take advantage of their economic precariousness, abuse their dignity and reify their will. Despite this, the creature's filiation is suspended in favor of those who provide the payment. All this, they intend to "make up" with an authorization of the "altruistic or solidarity maternity", which in short remains the same procedure, without publishing the money and compensations that mediate in this relationship.

\section{Conclusions}

Surrogate motherhood is an issue currently being debated in the legislative chambers of many countries. Colombia is no exception. The need for the law to adapt to social, cultural, technological and scientific developments in order to legislate on assisted human reproduction techniques has been identified.

Consequently, this text identifies that Bill 037 of 2009 and Bill 026 of 2016 are clearly based on the intention to legislate regarding surrogate pregnancy or surrogate motherhood. With respect to the excessive practice of this method of assisted human reproduction in Colombia, which is being developed with an erroneous figure such as a de facto contract, this does not find legality in the Colombian legal system, and is a violation of fundamental and constitutional rights of the unborn and exploitation of women for reproductive and economic purposes.

The purpose of Bill 026 of 2016 is to regulate the rental of wombs for altruistic and non-economic purposes. Project that seeks to protect rights such as life, human dignity and identity, thus avoiding criminal disputes between the participants in surrogate motherhood, gestational surrogate mother-genetic surrogate mother and the contractual parents.

\section{Conflicts of Interest}

The authors declare no conflicts of interest regarding the publication of this paper.

\section{References}

[1] COLOMBIA: CONGRESO DE LA REPUBLICA (1887) Law 57/1887. (May 23rd) 
By Means of Which the Civil Code Is Issued. Bogota.

[2] COLOMBIA. CÁMARA DE REPRESENTANTES (2009) PROYECTO DE LEY 037 DE 2009 CÁMARA. Por medio de la cual se establecen procedimientos para permitir en todo el territorio nacional la práctica de la gestación sustitutiva mediante las técnicas de reproducción humana asistida y se dictan otras disposiciones.

[3] COLOMBIA. CÁMARA DE REPRESENTANTES (2016) PROYECTO DE LEY 026 DE 2016 CÁMARA. Por medio de la cual se prohíbe la maternidad subrogada con fines de lucro en Colombia y se reglamenta su práctica.

[4] COLOMBIA. CONGRESO DE LA REPÚBLICA (2000) Ley 599 de 2000 (julio 24). Por la cual se expide el Código Penal. Official Newspaper No. 44.097, June $24^{\text {th }}$, 2000. Santa Fe de Bogotá, D. C.

[5] COLOMBIA: CONGRESO DE LA REPÜBLICA (2006) Ley 1098 del 2006. (noviembre 8) Por medio del cual se expide el Código de Infancia y Adolescencia. Bogotá.

[6] COLOMBIA: CORTE CONSTITUCIONAL (2016) Sentencia de constitucionalidad 683 del 2015 (noviembre 4) Magistrado Ponente. Jorge Iván Palacio Palacio, Bogotá. 